\title{
Planning for Inclusion of Refugees Understanding Initiatives taken for Sindhi Community of Bairagarh, Bhopal
}

\author{
Vallary GUPTA,Young Professional, Coalition for Disaster Resilient Infrastructure, New Delhi, India \\ Kshama PUNTAMBEKAR, School of Planning and Architecture, Bhopal , India
}

\begin{abstract}
Global human displacement is at a record high with the refugee crisis progressively becoming more urban. The partition of India in 1947 led millions of Sindhi Hindus to migrate to India. As the resources depleted, several inmates from camps in Rajasthan were transferred to Bhopal in 1950 wherein, they were resettled in Bairagarh (a military barrack) in the outskirts of the city. Bairagarh is a unique case as it witnessed refugee influx both before and after partition. Its rapid growth led to its inclusion in CDP in 1959-60.

The paper explores the case to understand the role played by government and local communities resulting in long term socio-economic integration of Sindhi refugees in Bairagarh. Study is done through discussions held with local communities, documentation of land values and growth in built-up area over the years. As a case Delhi is studied through literature to draw similarities.
\end{abstract}

The paper displays how in absence of any legislation, the strategic resettlement measures like provision of land for commercial establishments, development of social infrastructure by the state government has led to absorption of refugees into the community, they no longer consider themselves as outsiders but rightful citizens of the nation.

\section{Keywords}

Refugee, Resettlement, Migration, Bairagarh, Sindhi community

\section{Introduction}

The origin of the word Refugee can be traced from the old French word "refuge" (hiding place) then being used during the French revolution to refer to people fleeing France. It was only in the 18th century that the word began to refer to people escaping not only religious persecution but also war and violence. It was not until the 1951 Refugee Convention or Geneva Convention that the international law officially defined the term "refugee", during the first refugee crisis. The Convention defines refugee as a person forced to move across national borders due to fear of persecution for reasons like violence, race, religion, nationality etc., and outlines their rights to seek asylum and the responsibilities of other nations that provide asylum. At its core, lies the principle of non-refoulement that still applies today. As of 2020 , there are 146 member countries party to the convention which does not include India.

The convention provides the basis of work to the United Nations High Commissioner for Refugees or UNHCR which is a global organisation established during the aftermath of Second World War to protect refugees and safeguards their rights, provide assistance to asylum seekers and support in their voluntary 
repatriation and consequent resettlement in the third country. Resettlement as defined by UNHCR is the identification (in a state of persecution) and transfer of refugees from a state where they seek protection (country of asylum) to a state which agrees to resettle them (host country).

As per UNHCR, the global population of refugees over the past two decades has grown substantially from 33.9 million in 1997 to 68.5 million in 2018 mainly due to persecution, conflict, violence or violations of human rights. As of 2018, the organisation works in 128 countries, including India. One third of the refugee population across the world is hosted or resettled by countries like Pakistan, Uganda, Lebanon, and Iran as shown in Figure 1 below.

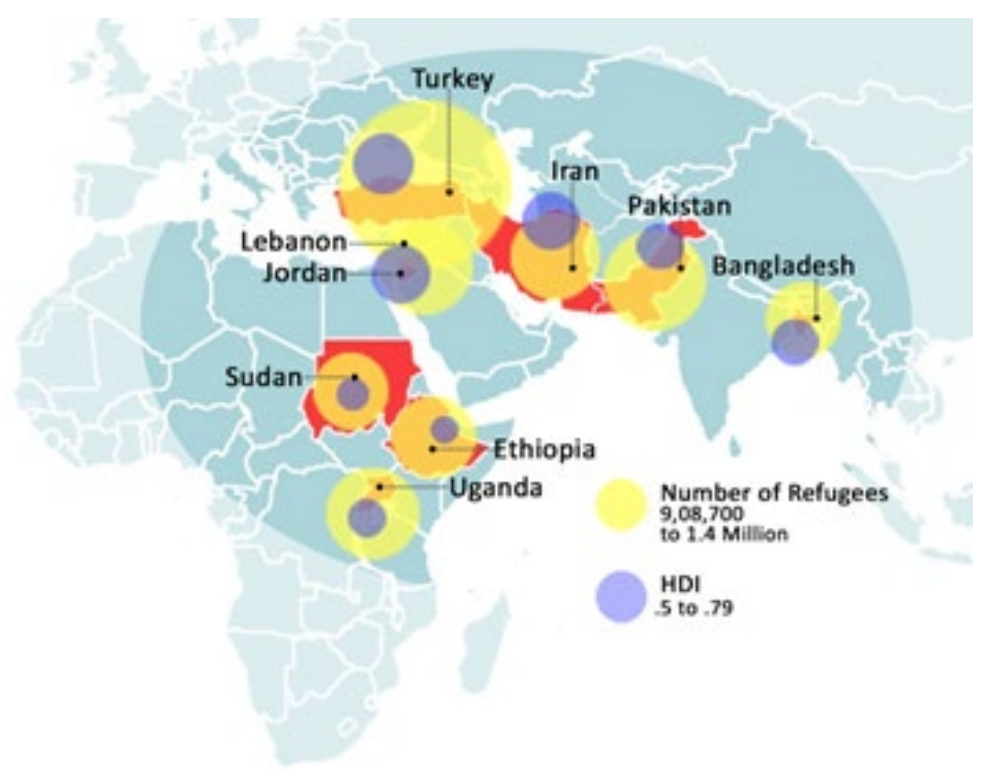

Figure 1: Countries with highest Refugee Population, (UNHCR, 2019), (UNDP, 2019)

The increase in the number of refugees worldwide highlights the need for long term resettlement measures. As per UNHCR, 60 percent of total refugees across the world live in cities. Urban areas in developing nations already grappling with minimum resources are burdened with large economic, social, and demographic crises. Various National and international cases highlight how displacement in addition to getting more urban in nature is increasingly becoming prolonged. This emphasises the need to adopt measures that intend to make refugees an integral part of the local community.

\subsection{Background}

India is neither a signatory to the 1951 UN Refugee Convention nor its 1967 protocol yet it hosts a large population. It is a signatory to a majority of the international instruments that have a direct bearing on refugee rights and protection. These include The International Covenant on Civil and Political Rights and The International Covenant on Economic, Social and Cultural Rights, 1966, The Convention on Rights of the Child, 1989, The Convention to Eliminate all forms of Discrimination Against Women, 1980, The Convention against Torture, and Other Cruel, Inhuman or Degrading Treatment or Punishment, 1984 (JIPS, 2013).

The Indian government respects decisions made by UNHCR and has allowed its operations in the country since 1981 in close cooperation with the Government of India, NGOs and civil society to support and improve lives of refugees and asylum-seekers. In absence of any specific refugee legislation in India, the Government has been adopting an ad hoc approach to resettle refugees in the country. 
As of 2016, 2,89,394 refugees live in India as per the Ministry of State for Home Affairs. Ranging from Buddhist Chakmas, Tripuris and Maug Tribals of Bangladesh, to Muslim Rohinygas from Myanmar, Sikhs and Hindus from Pakistan to Bhutanese from Nepal, and Bengalis, Tibetans and Tamilians from other countries, India is home to varied groups of refugees. Since independence in 1947 India has received large streams of refugees from four neighbouring countries, Pakistan, Bangladesh, Tibet and Sri Lanka.

In 1947, the nation witnessed one of the biggest migrations of 14.5 million persons in Indian history during India's partition into India and Pakistan. Distance to the border and proximity to large cities played a significant role in determining the destination of migrants (Prashant Bharadwaj, 2008).

By 1951 there were about 4.7 million Punjab refugees, three quarters of whom were concentrated in North-western India with as many as 60 percent in Punjab alone followed by Uttar Pradesh, Rajasthan, Madhya Pradesh, Maharashtra etc. (Amrita Paul, 2015). The bulk of the Sindhis, poor peasants, and traders were moved to Maharashtra and Madhya Pradesh (Hashmi, 2017).

In the year 1959 more than 100,000 followers fled Tibet led by the Dalai Lama. Tibetan political refugees in India were around 3000 concentrated majorly in northern and north-eastern Indian states of Uttaranchal (erstwhile Uttar Pradesh) and West Bengal (census 19561). Today India has 1,50,000 Tibetan refugees spread across Himachal Pradesh, Ladakh, Arunachal Pradesh, Karnataka, Uttar Pradesh, Madhya Pradesh, South Sikkim, West Bengal, Maharashtra and Orissa. (Amrita Paul, 2015). Another refugee swell was experienced in 1971 about ten million individuals moved to India including Bengali Muslims and the tribal groups.. They migrated to various parts of northeast India, Delhi, Mumbai, Odisha, Madhya Pradesh, Bihar and Chhattisgarh.

Sri Lankan Tamils form another sizable group who crossed the Palk Strait to India between 1983 and 1987. According to UNHCR, currently India is home to more than 2,00,000 Afghan refugees after the Soviet invasion of Afghanistan in 1979. Yet another refugee influx was observed in 2016 when 1.1 million displaced Rohingyas escaped Myanmar and took shelter in India. 


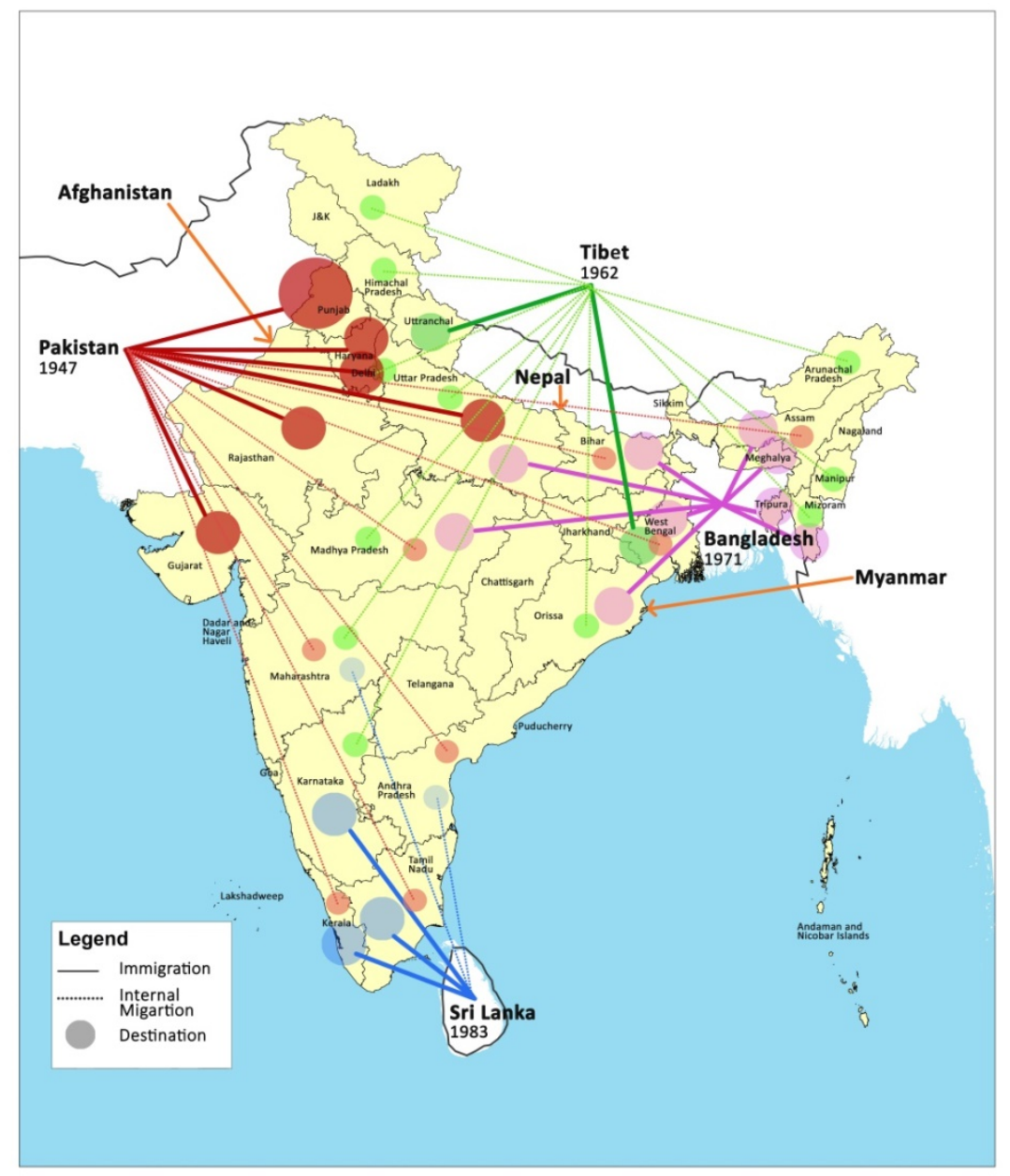

Map 1: Distribution of Refugees in India, Author generated based on (Amrita Paul, 2015), (Madhumita, 2015)

All migrations differed in their time, conditions, size, and the consequent strategies adopted for resettlement. However, the disturbing experiences that refugees underwent, in terms of leaving their country, facing violence and oppression in one's own land and settling in an unknown place were all same. Such events pose questions on their sovereignty, human rights, and relationship between states and nations and the international order. Becoming a refugee is an eventual loss of not just home but identity.

\subsection{Aim, Objectives and Methodology}

The research aims to identify the various measures taken by different countries to resettle refugees on foreign lands and its effect on patterns of long term integration and socio-economic development of the inmates. It attempts to ascertain the challenges faced by the displaced and host communities globally and analyse the spatial transformation arising from refugee inflow. The study further delves into developing an in-depth understanding of Refugee resettlement practices in the country in absence of any policy framework. It discusses the challenges faced by the refugee population and the host region with specific focus on India post partition.

The case of Delhi is developed and analysed based on secondary sources while the refugee township of Bairagarh entailing its socio- economic growth and demographical and spatial change is understood 
based on primary data collected through interviews and discussions with local residents and shopkeepers.

The study of prominent global cases helps to identify practices that led to long-term socio-economic integration of Sindhis within the local culture and community. The paper concludes by highlighting different responses taken by local authorities from across the globe for absorption and long-term resettlement of refugees. It highlights how despite the apparent similarity of being displaced, different groups of refugees confronted diametrically opposite situations, and thus employed varying strategies to earn back their self-dependence and craft for themselves a new identity.

\section{Understating International and National Migration Scenarios}

The growing global population, along with rising human conflicts and environmental change, is leading to an increased number of displaced across the globe. (UNHCR, 2019) suggests that in addition to persecution, violence, and conflict, that are the main reasons for sweeping displacement across the globe, natural disasters also contribute. Man-made calamities like socio-economic deprivation can also force people to flee across borders. For instance, violence, insecurity, persecution, and shortages of food, and other basics, made millions of Venezuelans leave their country (Moutafis, 2019).

Other factors responsible include civil war (Syria, Afghanistan), demographic reorganisation (Palestine and Israel), religious persecution (Muslims in Myanmar and Hindus in Pakistan), political persecution (Tibet), domestic conflicts (Sri Lanka), hunger, and deprivation (Somalia, Yemen), environmental displacement, human trafficking, and newly emerging climate change (Rueckert, 2017). Social tension around cultural and religious differences, instances of oppression, harassment and intimidation and rising instability in local, state, and national politics also add to the refugee crises (Bhavnani, 2016).

Recent literature originating from humanitarian organizations acknowledge that refugee crises should not be considered temporary situations which require only emergency responses, but protracted situations calling for durable long term solutions. Prolonged refugee situations characterize a significant challenge to both the refugee population and security of the host country. To prevent additional challenges, it becomes necessary that basic rights and essential economic, social, and psychological needs of refugees be fulfilled. The nature of a refugee situation depends on conditions of the country of origin, the responses of, and conditions in the host countries and the level of community engagement (Gil Loescher, 2006).

\subsection{Measures taken for Refugee Resettlement}

Emergency handbook by UNHCR suggests that planning for refugees should consider long-term provision of services, highlight the need for a 'bottom up' approach, preserve traditional social arrangements and emphasise on need for consulting all stakeholders including refugee and host community (UNHCR, Camp strategy guidance (planned settlements), 2019). Globally, several countries have taken initiatives and implemented policy measures for rehabilitating refugees and improving their living conditions.

Germany for instance has its own federal quota system for distributing refugees based on total population. To engage community participation and building of non-traditional housing, restrictive federal laws have been reformed to cater to needs more effectively. Necessary steps have been taken by city-level leaders, both public and civic to integrate the displaced and identify both short-term and longterm affordable housing options (Bruce Katz L. N., 2016). 
The refugee influx in Jordan impacted service delivery and created need for humanitarian assistance, making national government introduce Jordan Compact to provide 200,000 work permits to refugees. Municipalities provided assistance to Syrian refugees and access to basic amenities (Forum, 2018).

Countries like Norway and Canada focuses on integration of refugees by providing them access to education and employment. Canada also greets its refugees on arrival and helps them understand the host through training to increase the integrity between the locals and refugees (Congress, 2016).

Research suggests that the concerned authorities should prioritize areas based on needs of refugees and adopt a long-term developmental approach by empowering the local community based organizations, through training and financial support and also by poverty alleviation schemes and income generation projects as in case of Canada and Norway (Jawabrah. Muain, 2016). Access to basic services should be ensured to maintain a safe environment for both locals as well as immigrants. The provisions should be as per local context to avoid any obstructions due to language and cultural barriers.

\subsection{Impacts of Displacement on Host}

According to the International Organization for Migration's 2015 Migration Report, two-thirds of all refugees world over live in urban areas. They settle disproportionately in large cities to have access to better jobs where they face social and spatial challenges related to accommodation and integration. Selecting a site for setting up of camps is thus a critical factor to be considered to promote community cohesion and efficient access to services. Identification of close cultural affinities between refugees and their host communities becomes important and should be done at an early stage to reduce tensions (Veronika Fajth, 2019).

History shows that refugee camps located on city outskirts slowly grow and are subsumed in city limits, often beginning to thrive as separate economic hubs. For instance, Ulhas Nagar in Maharashtra is one of the largest Sindhi communities in India and is one of the largest denim jeans manufacturers with a number of small manufacturers exporting quality denim jeans worldwide.

A contrasting example shows that arrival of a large number of Syrian refugees in Lebanon caused tensions between refugee and host communities and between local communities and administrative authorities. Studies reveal that growing social tensions generated secondary conflicts (International, 2015). An International Alert report, 2015 illustrated the concerns of Lebanese nationals about becoming victims of crime, poverty, service shortages. Such issues also affect use of public spaces and mobility within the host regions (Alert, 2015).

Other concerns include difficulty in accessing affordable housing and physical infrastructure as in the case of Gaza where an increasing population exerted pressure on already stressed resources (Jawabrah. Muain, 2016). The growing population implied an increasing pressure on the economy to absorb an expanding labour force and caused social issues like privacy, poverty, and conflicts arising due to space constraints.

Refugee inflow exerts impacts on economic goals, production systems and on behaviours and attitudes of the host country, affecting sustainability and quality of life of the host community (Jawabrah. Muain, 2016). The (UNHCR, 2019) shows that the sectors that become most critical in the host country as a result of refugee inflow include education and shelter provision.

\subsection{Impacts of Displacement on Refugees}

Refugee rehabilitation cases from across the world show that refugee camps end up making its residents more vulnerable and do not always ensure security. The closed environment exposes refugees to several 
threats like theft, gender based violence, early marriage, assault, child abuse, rapes, arson, enslavement and others.

Lessons from Gaza reveal that overcrowding in camps lead to emotional trauma and insufficient supply of social infrastructure like reduced per capita open space, unhygienic conditions, cultural trauma, and reduced privacy. It causes marginalization of the weak and raises greater concerns for the safety of women and children. (Jawabrah. Muain, 2016).

The case of Syrian conflict highlights that both authorities and refugees struggle to adjust to long term social, economic, and demographic shifts. As of December 2017, UNHCR recorded 6,55,624 registered Syrian refugees in Jordan (UNHCR, 2019) who continue to face obstacles to economic opportunities, quality education, and access to basic services.

The 1971 migration from Bangladesh to India presented yet another grim image of displacement leading to widespread death and disease in absence of homes, little or no food, and insufficient medical supplies (Francis, 2016). All these issues bear a greater long-term impact as it leads to risks of serious mental health trauma, depression and anxiety and end up affecting the integration and cohesion of displaced amongst themselves and with the local communities (Bruce Katz L. N., 2016).

(Manual for UNRWA Employment Service Centres, 2013) suggests that refugees feel an increasing wish to interact and integrate within the locals and thus prefer visiting community centres to socialise and acquire new skills.

\subsection{Measures for Relief and Rehabilitation in India after Partition}

On August 15, 1947, the nation woke up to freedom and witnessed the nation's biggest migration. It was time when choices were made. During partition in 1947, Punjab was divided but Sindh Province was kept intact. The Hindus in Sindh were forced to migrate to India due to subsequent incidents of violence in Sindh (lyer S. , 2001).

The wealthy elite and powerful Hindu Sindhis who were in minority in the state became homeless and penniless overnight as they moved to India. On reaching India, they were dispersed or accommodated in relief camps set up in and around major urban centres. Bombay received the largest number of refugees from Sindh and became home to 1,29,000 refugees. The map below shows the settlement distribution of Sindhi population as per the Census of India post partition (Census of India, 1941, 1951). The census reports of 1951 show that the majority of the Sindhi refugees settled down in Kutch, Bombay, Rajasthan, Saurashtra, Ajmer, Madhya Pradesh, and Delhi. 


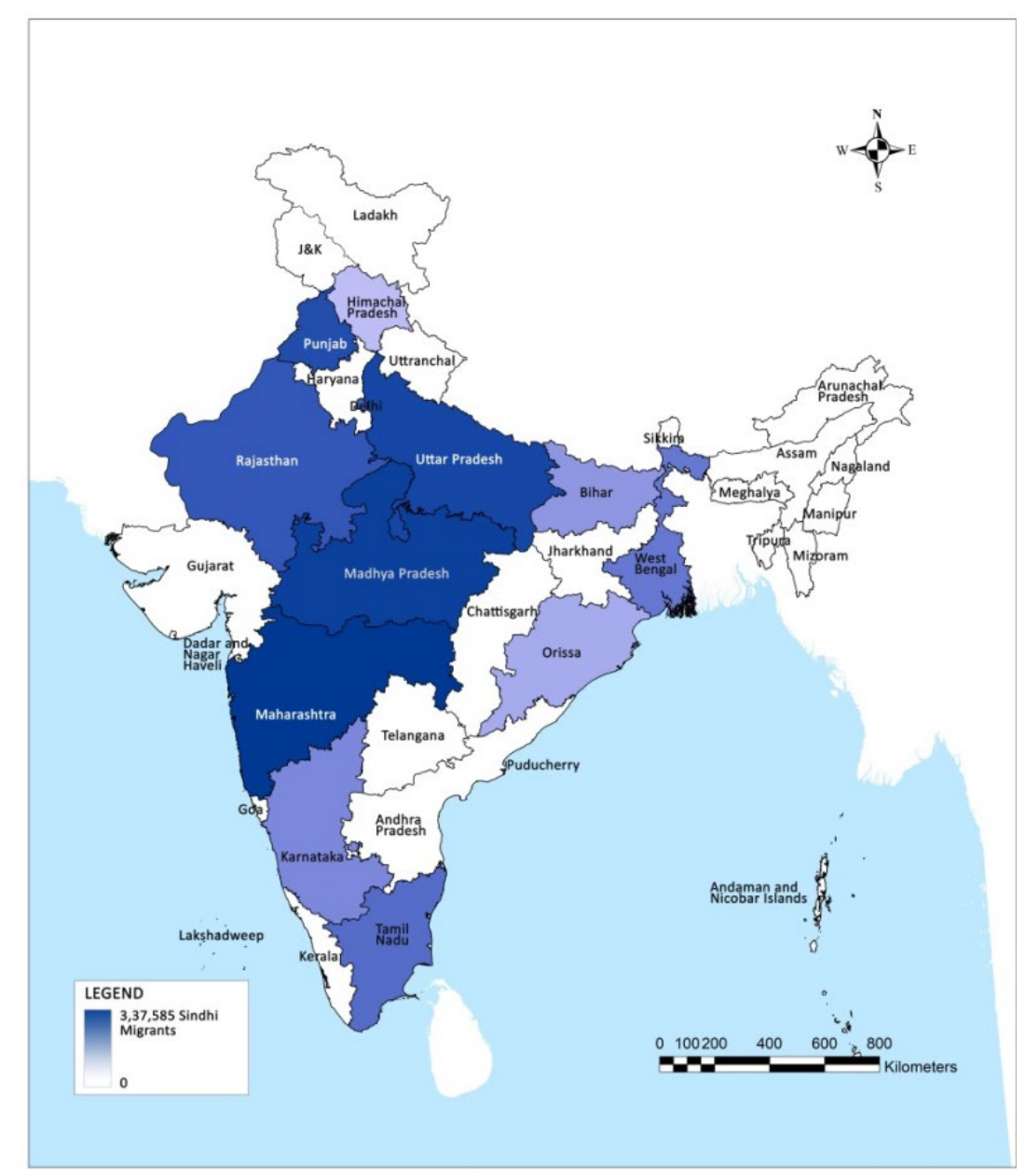

Map 2: Post Partition settlements of Sindhi population as per Census 1951, Census of India, 1951

As per 2001 Census, approximately 92 percent of the Sindhis were concentrated in the present day states of Maharashtra, Gujarat, Rajasthan, Chhattisgarh and Madhya Pradesh (Bhavnani, The Making of the Exile: Sindhi Hindus and the Partition of India, 2014). Erstwhile refugee camps such as Kalyan (now Ulhasnagar) and Kubernagar (in Ahmedabad), are today Sindhi-dominated neighbourhoods.

The migration received support from the Sindh government which relaxed its rules, allowing employees to withdraw advances from their provident fund, and granted leaves. Special trains were plying from Sindh to Rajasthan. 10,00,000 Hindus had migrated to India.

As the evacuation neared an end, Government of India began its provision of relief and rehabilitation to the displaced after partition (Committee, 1948). Relief measures were followed by permanent rehabilitation that involved both rural and urban rehabilitation programmes. The state in absence of any permanent policy and support on rehabilitation relied on legislative measures alone. Camps were set up to provide relief to the displaced while simultaneously estimating the number of permanent rehabilitations. The refugees were classified into men who could be recruited in available jobs, women who could be employed or were required to be housed in special homes, and the old who were to be housed in the permanent liability camps.

Policies were laid out for housing, employment, and education of the migrants. Directives were issued to all State Governments for housing of the displaced, whereby states were to identify suitable sites and facilitate construction of houses therein. The Office of the Director General of Rehabilitation and Employment was set up to provide employment. Migrants were enlisted and given the first priority in 
government office vacancies. Vocational training centres were also set up to train migrants in small handicrafts that could help them set up small business enterprises (JIPS, 2013).

The camp locations were selected with an intention to provide permanent rehabilitation in future. Planners while choosing camp locations were asked to consider the proximity to the township to be developed. Along with the Government, the local population also contributed actively by bringing refugees from railway stations and housing them in mandirs, schools and gurudwaras, and providing them with food and small amounts of money to initiate work.

The acts that strengthened the position of migrants in the country include Administration of Evacuee property Act, 1950, the Claims Act (1950) and the Displaced Persons Compensation and Rehabilitation Act (1954) (Shodhganga). To accommodate refugees the Government of India followed the order of Evacuation- Relief- Permanent Rehabilitation and Compensation.

\subsection{Case Study- Delhi}

Delhi being the National capital became a popular site for incoming Refugees received 4,95,391 refugees from western Punjab and Sindh. By 1951, 28.4 percent of the city's population comprised refugees with 47 per cent of Pakistan born migrants (Pandey, 2001). The period from 1941-51 saw the highest demographic growth in the history of the capital which expanded from 6,96,686 inhabitants in 1941 to $14,37,134$ in 1951, resulting in an annual growth rate of 7.5 per cent (Census of India, 1941, 1951).

The city's spatial expansion underwent a simultaneous change as residential densities increased from 40 to 70 in a decade and (Census of India, 1941, 1951), the spatial expansion of the urban zone in all directions as shown in Map 4. The 'official' urban area of Delhi almost doubled from 174 sqkm in 1941 to 326.5 sqkm in 1961 (Dupont V. , 2004). 

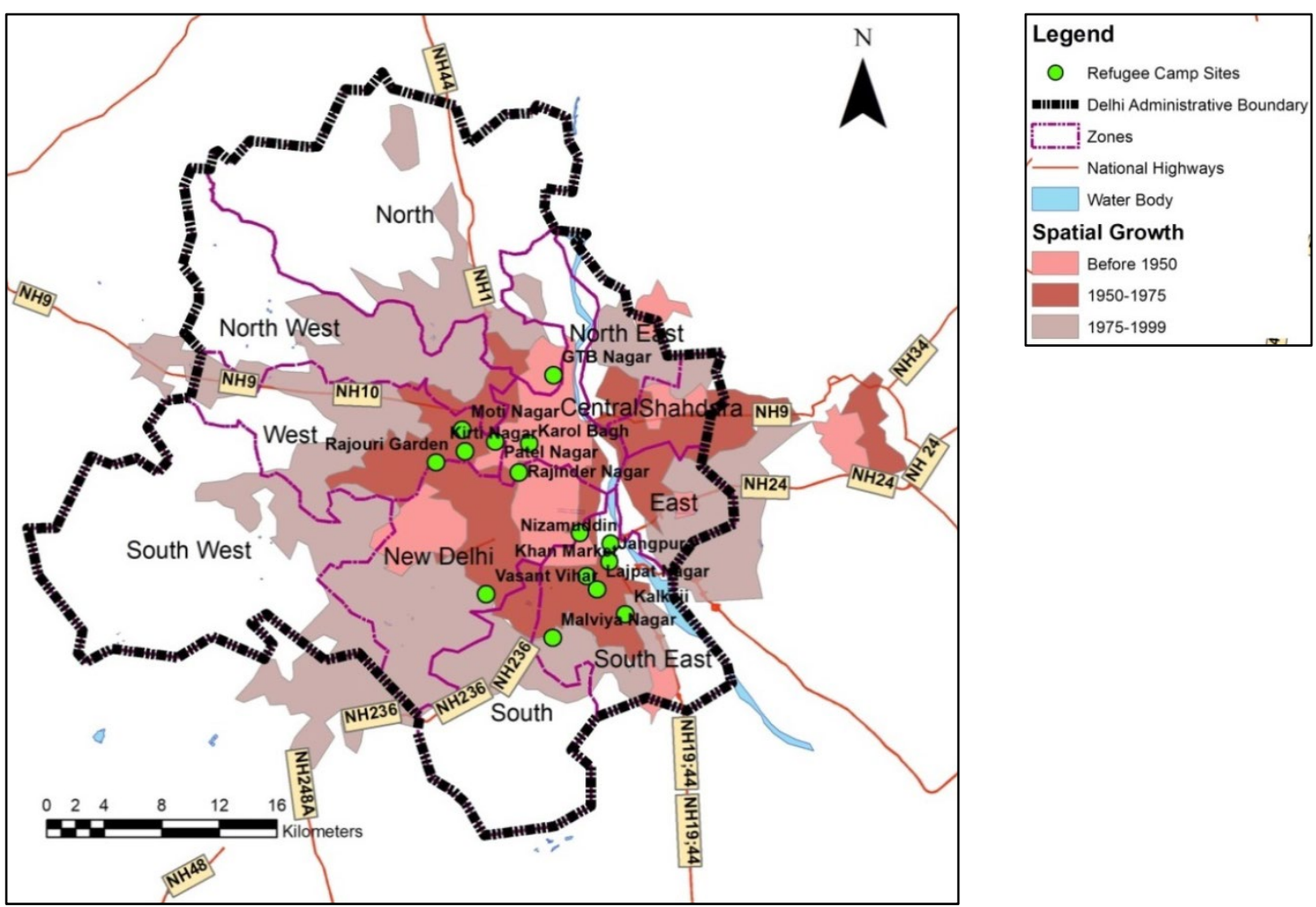

Map 3: Built-Up changes in Delhi, (Census, 1991), (NCRPB, 1988), (DDA, 1990), (Ltd, 1996)

Prior to 1947, Delhi's western limit was Karol Bagh; later the empty lands to west of it began to be allotted to refugees. This marked the beginning for refugee colonies like Rajinder Nagar, West Patel Nagar, Moti Nagar, and Rajouri Garden. It was during the middle of the 1950s that refugees moved to empty flats in Lodhi Colony and built homes around the villages in Nizamuddin and Jangpura. As per 1951 census, the Indian government had allotted 2,000 acres of land to the Ministry of Relief and Rehabilitation to permanently resettle refugees. As shown in Map 3, Southern Delhi thus began to take shape by 1956 with the appearance of Lajpat Nagar and Defence Colony (Bhatia, 2010).

\subsubsection{Analysing the results of Rehabilitation Exercise}

A major portion of the arriving refugees resettled into evacuee properties (properties left by outmigrating or displaced Muslims) or new government-built housing localities. Under the Administration of Evacuee property Act, the State demarcated property 'evacuee property', and allotted these to the incoming refugees. People with proper documentation of their previous holdings in Pakistan, could request a commensurate property.

Refugees in Delhi in addition to Evacuee Properties, also resettled into 100,000 new housing units provided by the government (Datta, 1986). The government passed the 'Resettlement of the Displaced Persons (Land Acquisition) Ordinance, 1948 wherein land for resettling the refugees was acquired in and around Delhi by the government and a suitable compensation was given to the original owners. The plots were distributed among the displaced persons and used for the purpose of construction of homes and shops, either by the migrants themselves or by the government (Rehabilitation, 1953). 
Most parts of Delhi we see today grew largely out of the refugee camps that sprung up 69 years ago. A large number of rehabilitation colonies came up on open fields, former farmland, and ridge forests. The entire city of Faridabad, Haryana was built to rehabilitate refugees. Later it developed into a full-fledged industrial township of Faridabad. Similarly, the camp at Rajpura was set up for the rehabilitation of refugees in the twin townships of Tripuri and Rajpura.

As a result of this, many refugee colonies came up in erstwhile forest and scrub lands of South Delhi where the government began buying lands for permanent rehabilitation of refugees. Colonies began to sprung up at Pusa Road, Malviya Nagar, Nizamuddin, Kalkaji, Patel Nagar, Rajendra Nagar, Jangpura, Lajpat Nagar, Tilak Nagar, and Kirti Nagar as shown in Map 4. South Delhi was a chosen site due to the benefits of height and less river bodies in comparison to the other parts of the city.

The colony layouts were approved by the Town-Planning Sub-Committee and the Delhi Development Sub-Committee, and sponsored by the Ministry of Rehabilitation in cooperation with the Punjab National Bank. The colonies were well planned and to great extent supervised by the government. The plots were to be freehold and provision of sites for school, dispensary, cinema, petrol pump, public buildings etc. was made.

Some of the earliest colonies from 1951 include Vijay Nagar, Model Town, and Kingsway Camp (Bhatia, 2010). The high street market spaces like Meher Chand Market, Khanna Market, and Khan Market we see today were built then wherein the shops were allocated to displaced people from Pakistan (Lidhoo, 2016). The Ministry of Rehabilitation extended facilities to refugees for establishing small-scale industries in Malviya Nagar and Kalkaji. They were provided loans and concessions by the government and about 25 industries were allotted to them. Okhla Industrial area was later on also built for other refugee enterprises (Datta, 1986).

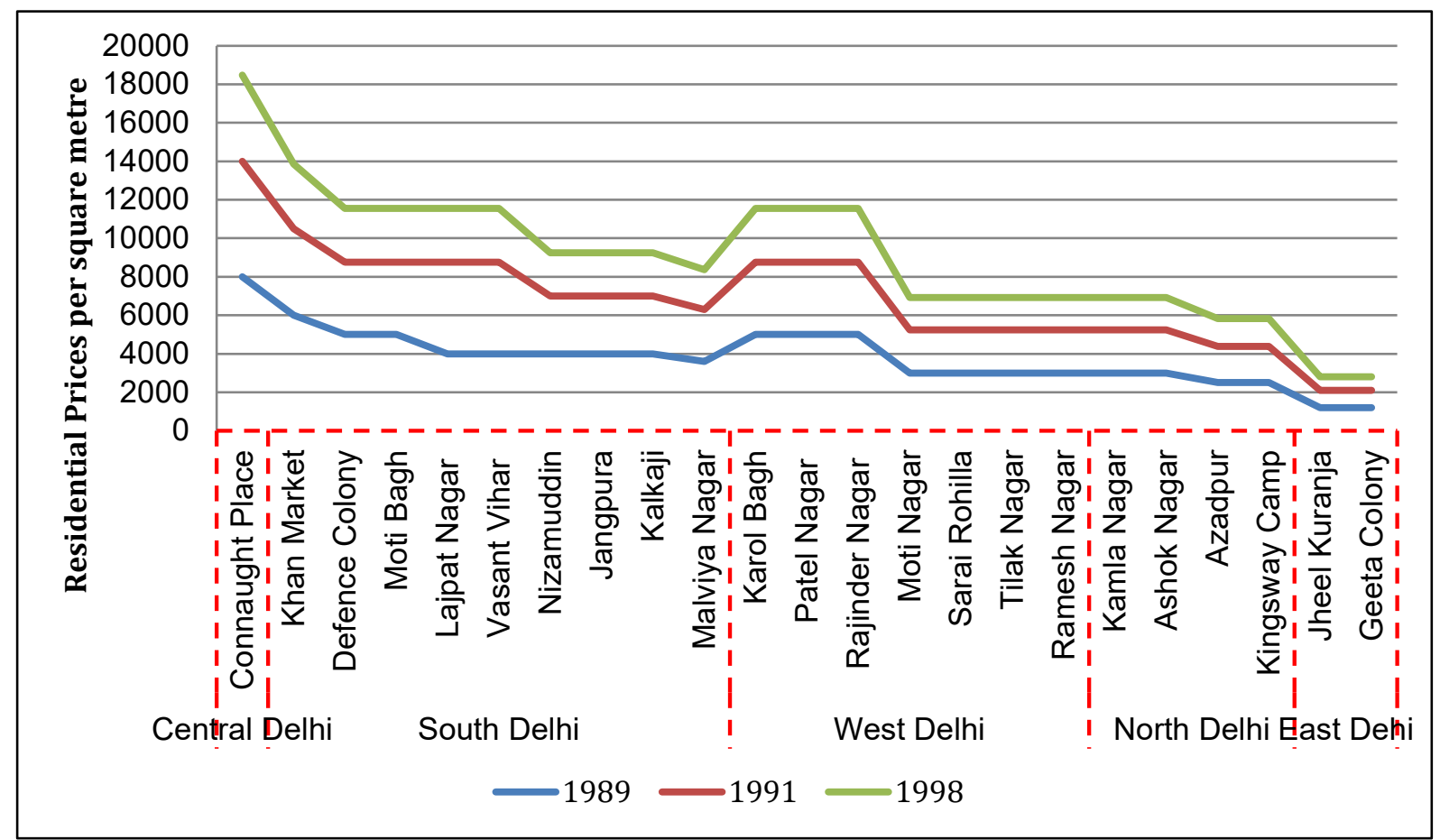

Graph 1: Comparative Residential Land Prices, Ministry of Finance

Graph 1 above shows that the residential land prices in Central Delhi are today comparable to those of South Delhi. The localities like Lajpat Nagar, Nizammudin, Malviya Nagar and others are the major 
residential concentration of traders and businessmen with some of them commanding the highest land prices in the city. The comparable prices are a reflection of the socio-economic stability of the community and their absorption and acceptance by locals and authorities. Many well-off refugees over the years have moved to many affluent areas of Greater Kailash, New Friends Colony, Vasant Vihar, and Defence colony. The community today is an indispensable part of local and national economy with places like Karol Bagh housing majorly the new upper and middle-class merchants and other entrepreneurs of Punjabi refugee origin (Dupont V. , 2002). The case thus highlights a positive picture of long-term effects of the government's efforts during initial years after partition.

\section{Case Study 2- Bairagarh, Bhopal}

As the status of the camps in states that saw early migration was crammed and rudimentary requiring heavy expenditure on resource procurement, inmates from a camp at Deoli, Rajasthan were transferred to Bhopal by 31st October 1949 (Iyer S. , 2001). wherein they were resettled primarily in the western town of Bairagarh in the city outskirts along with centrally situated Gandhi Nagar and Sindhi Colony. Bairagarh is a unique case as it witnessed refugee influx both before and after partition

Once a princely state from 1818 to 1947 , and an independent state till 1949, Bhopal was taken over by the Union Government of India on 1st June 1949 (District Census Handbook, Bhopal). The Sindhi refugees during the 1950s were resettled primarily in the western suburb of Bairagarh towards the outskirts of the city of Bhopal in addition to other two central locations of Gandhi Nagar and Sindhi Colony. As per 1961 census, the residents of Bhopal born in Pakistan accounted at 17,946 that was as much as 10 percent of Bhopal's population.

\subsection{History of Bairagarh}

A military township created for prisoners of Second World War was planned by the government to facilitate absorption of refugees and provide shelter in its abandoned barracks. The Sindhi community that occupies the majority of Bairagarh today includes migrants who originally settled in Hyderabad, Surat, Gandhi Nagar, and Jaipur. They migrated to India in 1947 but reached Bairagarh only in 1950. The area witnessed refugee migration both before and after partition with peak migration during the 1950 s. The migration before partition as highlighted by (Bhavnani, 2016) was chiefly a means to escape instances of oppression, harassment, and intimidation. People migrated mainly owing to fear of communal discrimination and oppression, in addition to loss of social status in Muslim-dominated Pakistan. Residents on interview revealed that the forced conversions of Sindhi community to Islam were rampant in Pakistan during the time. The population of Bairagarh increased from 400 to nearly 14,000 from 1941 to 1951.

The refugee town of Bairagarh once covered by jungle prior to refugee influx has drastically grown since 1951 as shown in Map 4. Initially converted into residential areas, the town was later turned into commercial land use along the Bhopal-Indore road. The Bhopal municipality was established in 1916 and the city limits were revised in 1958 in order to include more adjoining villages after it was declared as capital of the state. It was only in 1959-60 that a conscious planning effort was taken in the form of Development Plan. The military cantonment was moved to Bairagarh area. 


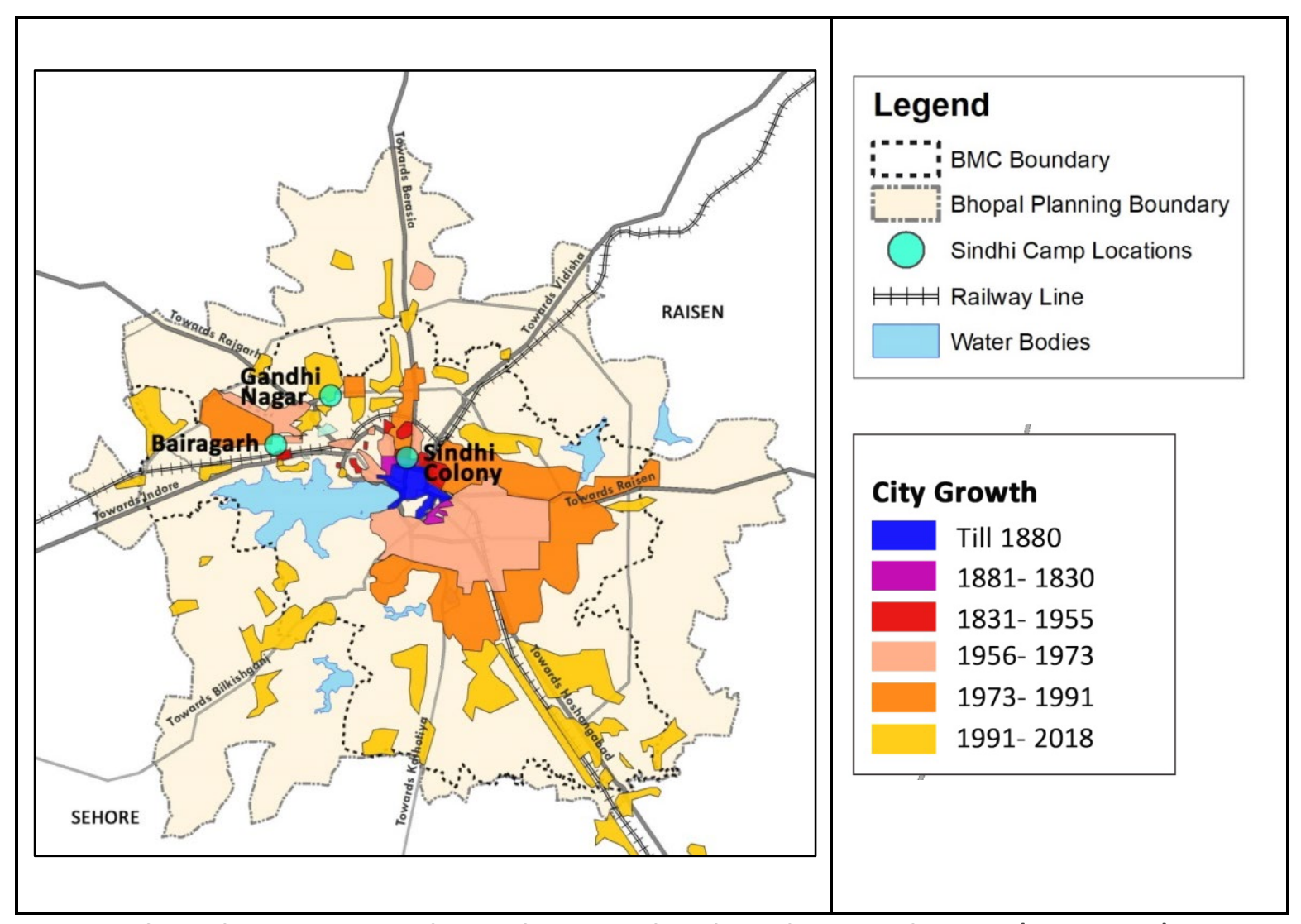

Map 4: Built Up change in Bairagarh over the years, Bhopal Development Plan 2005 (DTCP, 1994)

The built-up in Bairagarh over the years has shown considerable densification in residential areas. As per 1961 census, 52 percent of the housing area was under sub-standard conditions. Large scale renovation measures were taken around 1961 in housing by authorities (DTCP, 1994).

\subsection{Narratives from the Sindhi Community}

The Sindhi Hindus were originally a wealthy community who had a luxurious lifestyle. They held the highstatus positions of traders, shopkeepers, money-lenders, land-owners, teachers, and administrators at their native place. Majority of the community had undergone formal education and were employed in respectable positions. Respondents revealed that the community led a luxury lifestyle with multiple domestic helpers and caretakers to cater to daily chores being a regular practice.

However, during the early years after partition, they began to face financial stresses and were forced to live in extreme poverty. There was pain, confusion, and fear of being on foreign lands amidst new communities. While some of them could afford to rent or buy accommodation in India, or take shelter with family or friends in India, others became victims of grim migration processes and were forced to leave all their valuables in Sindh. The latter category of refugees were housed in camps set up on the city outskirts and were given free ration (Manjulalwani, 2015).

A former community of traders and merchants worked enormously hard to rehabilitate themselves. Having led a decent life with financial autonomy in Sindh, the community began rearing cattle, hawking goods on footpaths to become self-dependent and regain the lost identity. They resented the very term 'refugee' and interpreted it as pejorative terms implying weakness, helplessness, and dependency. The 
community in order to fulfil their native demands on new lands, started producing products of Sindhi tastes at reasonable prices and selling them on platforms and railway stations (Bhavnani, 2016), (Manjulalwani, 2015).

The government till 1950 helped Sindhi migrants by providing them with barracks to stay and later on land for constructing houses, shops for performing business, and small financial help in terms of loan. With aid from the government and using their business wisdom, the people started their own businesses to recover from poverty. All families kept together and helped each other in the closed community.

Many shops and establishments began to emerge in the vicinity of Bairagarh. Many establishments dealing in items like food, textile, soap, dying, bidi, biscuit, candy, pickle, and sweets started to flourish. They eventually got employed in respectable jobs or began working as a cloth merchant, a grocer, government servant, or a banker. Respondents said allotment of land for constructing houses gave them the sense of security and right to ownership that inspired them to invest in small business and eventually take up other jobs as well.
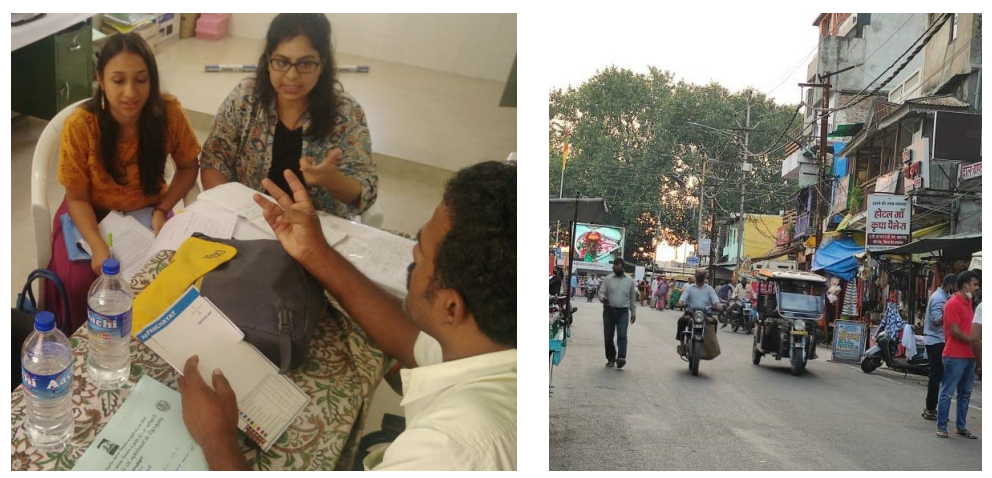

Figure 2: Interviews conducted with Local Traders in Bairagarh, Bhopal

Many small scale enterprises came up which majorly included saw mills, hosiery factories, cloth printing and dyeing, thread dying, readymade clothes amongst others for sale in Bhopal and later on for exports to several parts of Madhya Pradesh. Once a Military barracks and then site for refugee camps, Bairagarh thus started developing as a market town. As per 1951 census, 6,567 Sindhi refugees out of a total of 10,609 were engaged in commercial activity and 5,839 in service sector.
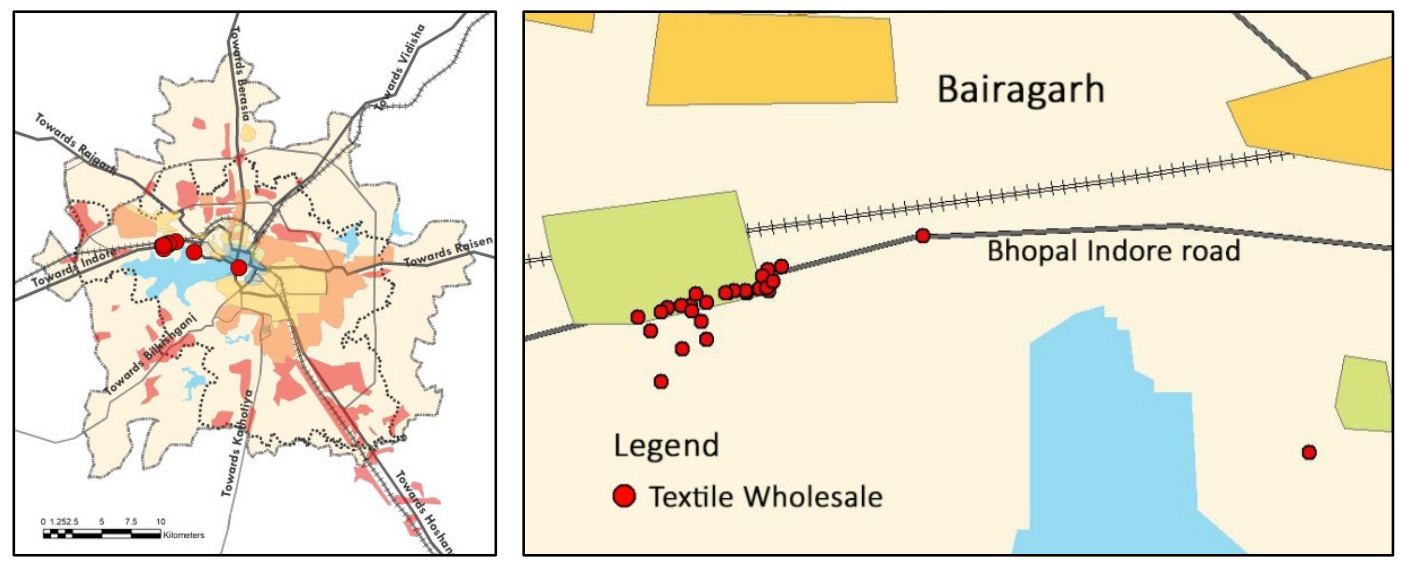

Map 5: Spatial Distribution of Textile Wholesale dealers in Bhopal 
The Map 5 shows the concentration of textile wholesale dealers in Bhopal, highest being in Bairagarh. Bairagarh, the once quiet township is now a bustling town that has turned into a sub-city of its own hosting the largest textile wholesale market for the region. With passing years, a large number of people got absorbed in the public sector with a higher percentage getting employed in banks. Children who were earlier sent to the only government school present in Bairagarh, later on found options to select from multiple schools and colleges in the city.

\subsection{Social Challenges faced by the Sindhi Community of Bairagarh}

The community during early years faced resentment from locals who perceived them as dirty for reasons like consumption of non-vegetarian food. The locals despised the women's traditional dress. The community respondents recall that as children, other children would not play with them (Kothari, 2009).

Sindhi Hindus adapted to local culture and learned local language to gain acceptance. They took active participation in local festivals and more Sindhi women took to wearing Indian saree or salwar-kameez. The community even voluntarily restrained their own ethnic culture and identity. Though the bitterness due to previous experiences was innate in their culture, both the communities in Bairagarh shared a fine rapport.

It was during the 1992 riots, that the challenges scaled up and the Sindhi communities located in the Old city area became critically sensitive. The hostilities in reaction to Babri Masjid demolition in Ayodhya were felt across the Sindhi settlements of Bairagarh, Gandhi Nagar and Sindhi Colony, however with varying intensities. Discussions with respondents reveal that Sindhis used to be careful and always felt protective of the Muslim community. However, the 1992 riots fuelled it and the experiences varied significantly amidst the three locations. The riots agitated the Muslim community of Bhopal. Gandhi Nagar and Sindhi colony being in city core were surrounded by Muslim communities and thus became easy and soft targets for social eruptions like violence, conflicts, and physical abuse of Sindhi women. The riots ended up deteriorating the already strained relationships between Sindhis and Muslims. Bairagarh due to its remote location remained comparatively unaffected from the social unrest.

\subsection{Remembering Sindh}

The respondents narrate that the generation who witnessed and overlooked partition still reminisce about their home land. Unlike other migrant communities who consider themselves as diasporas, Sindhi Hindus no longer perceive Sindh as a place they would ultimately wish to return to. The provincial Sindhi identity over the years has translated into loose attachments with only personal nostalgia of one's home remaining. Also, with creation of Pakistan came the transformation of erstwhile Sindh into a Muslim dominion. Thus moving away from Sindh was a safe homecoming experience for them, and thus they never think of themselves as outsiders (Bhavnani, 2016). Today, the community is happy to be in India. For them Pakistan was always equivalent to Islam. The small population of Sindhi community which could not migrate have been converted to Islam, however they continue to follow Sindhi customs and traditions.

\section{Conclusion}


Sindhi Hindus in Delhi and Bairagarh in India, Syrian refugees in Lebanon and Jordan and refugees from Palestine in Gaza strip were initially provided with relief measures and accommodated in camps. However, the rehabilitation processes and thus the long-term integration varied across cases (annexure 1). The refugees from Syria and Palestine faced resentment from local communities and with limited help from local authorities were left socially and economically immobile. The issues have had an impact on their long term integration and they continue to face hurdles in accessing basic services. Though the migrant settlements have today been absorbed into the urban area boundaries with cities growing around them, the people continue to face difficulty getting socially absorbed.

The case examples from Delhi and Bairagarh also display that refugees during initial years after partition faced challenges but the simultaneous initiatives taken by authorities to provide them with permanent rehabilitation, and livelihood lend them a sense of security and ability to carve their own identity on foreign land. Coupled with the efforts of migrants and host communities, the measures taken ensured their long term absorption and acceptance culturally, spatially and socio-economically. The comparable residential land prices of refugee colonies with central Delhi and ahead of the other parts of Delhi is a testimony of the absorption of refugees within the city and the local community.

The spatial and economic growth of Bairagarh from military barracks to a sub-city today along with being a major textile producing hub sings of the glory, and hard work of all associated being Sindhi Hindus (refugees), local communities and local authorities. The Hindu Sindhis eventually began to find their way around accepting and settling in unfamiliar lands. The amicable government interventions and gradual acceptance by locals, made refugees feel at home away from home and establish themselves as successful entrepreneurs. Today, the community owns huge business enterprises, are employed in wellpaying services, and growing to prosperity.

Though most of the Sindhi Hindus are away from their roots, they are happy and feel content about the choices made decades back. For most, Sindh has become a land of the past, and they consider themselves as rightful citizens of an independent India and have always considered themselves as belonging to India. 


\begin{tabular}{|c|c|c|c|}
\hline Refugee & Syrians from Syria & Palestinians From State of Palestine & Sindhis from Sindh, Pakistan \\
\hline $\begin{array}{l}\text { Reason for } \\
\text { Migration }\end{array}$ & Civil War 2011 & $\begin{array}{l}\text { 1948Palestine War; Demographic } \\
\text { changes; Ethnic cleansing }\end{array}$ & $\begin{array}{l}\text { India-Pakistan Partition 1947; } \\
\text { Forced conversion to Islam, } \\
\text { and conflicts }\end{array}$ \\
\hline $\begin{array}{l}\text { Population } \\
\text { Effected }\end{array}$ & 22 million & $\begin{array}{l}7,00,000 \\
\text { Today: } 5 \text { million }\end{array}$ & 14.5 million \\
\hline Host Country & $\begin{array}{l}\text { Turkey, Lebanon, Jordan, Egypt and Iraq, } \\
\text { and } 6.6 \text { million internally displaced } \\
\text { within Syria }\end{array}$ & $\begin{array}{l}\text { Jordan, Lebanon, the Syrian Arab } \\
\text { Republic, the Gaza Strip and the West } \\
\text { Bank, including East Jerusalem. }\end{array}$ & $\begin{array}{l}\text { Maharashtra, Gujar at, Punjab, } \\
\text { Uttar Pradesh, Rajasthan, } \\
\text { Haryana and Delhi in India }\end{array}$ \\
\hline $\begin{array}{l}\text { Government } \\
\text { Provisions }\end{array}$ & $\begin{array}{l}\text { Regional Refugee and Resilience Plan } \\
\text { (3RP) launched to coordinate } \\
\text { humanitarian help between UNHCR, } \\
\text { governments, and NGOs. Municipalities } \\
\text { provide aid and assistance. } \\
\text { Lack of national regulations w.r.t camp } \\
\text { and informal settlements supervision. }\end{array}$ & $\begin{array}{l}\text { UN Relief and Works Agency looks } \\
\text { after services, food assistance, and } \\
\text { administration; Security lies with host } \\
\text { region. }\end{array}$ & $\begin{array}{l}\text { No policy; employed } \\
\text { legislative measures } \\
\text { Constructed houses/ Plots for } \\
\text { construction of houses, skill } \\
\text { training, employment, shops, } \\
\text { and financial help. }\end{array}$ \\
\hline
\end{tabular}

\begin{tabular}{|c|c|c|c|c|}
\hline Refugee & & Syrians from Syria & Palestinians From State of Palestine & $\begin{array}{l}\text { Sindhis from Sindh, } \\
\text { Pakistan }\end{array}$ \\
\hline \multirow[t]{2}{*}{$\begin{array}{l}\text { Resettlement } \\
\text { Measures }\end{array}$} & $\begin{array}{l}\text { In earlier } \\
\text { years after } \\
\text { migration }\end{array}$ & \multirow[t]{2}{*}{$\begin{array}{l}\text { Rented houses, informal } \\
\text { settlements of tents or sub- } \\
\text { standard dwellings, garages, } \\
\text { workshops, prefabricated } \\
\text { shelters }\end{array}$} & Camps & Camps \\
\hline & Today & & $\begin{array}{l}30 \% \text { still in Camps- High population } \\
\text { density and poor living standards }\end{array}$ & $\begin{array}{l}\text { Land allotted for houses } \\
\text { in City outskirts; Legal } \\
\text { owner ship of land and } \\
\text { property. }\end{array}$ \\
\hline \multirow[t]{2}{*}{$\begin{array}{l}\text { Socio- } \\
\text { Economic } \\
\text { Pattern }\end{array}$} & $\begin{array}{l}\text { In earlier } \\
\text { years after } \\
\text { migration }\end{array}$ & \multirow[t]{2}{*}{$\begin{array}{l}\text { Daily wage workers, majority } \\
\text { below poverty line. }\end{array}$} & Unemployed and Deprived & $\begin{array}{l}\text { Involved in animal } \\
\text { rearing Land owners } \\
\text { Hawkers }\end{array}$ \\
\hline & Today & & $\begin{array}{l}50 \% \text { Unemployment; No access to } \\
\text { Public employment. Employment } \\
\text { service Centres by International Labour } \\
\text { Organization (ILO) and the United } \\
\text { Nations Relief and Works Agency } \\
\text { (UNRWA) provide assistance on } \\
\text { vocational training, and self- } \\
\text { employment opportunities to refugees. }\end{array}$ & $\begin{array}{l}\text { Businessmen, Traders } \\
\text { and service-men }\end{array}$ \\
\hline
\end{tabular}




\begin{tabular}{|c|c|c|c|}
\hline Refugee & Syrians from Syria & $\begin{array}{l}\text { Palestinians From State of } \\
\text { Palestine }\end{array}$ & $\begin{array}{c}\text { Sindhis from Sindh, } \\
\text { Pakistan }\end{array}$ \\
\hline Infrast ruct ure & $\begin{array}{l}\text { Increased population led to shortage } \\
\text { of resources- water and electricity. } \\
\text { Overcrowding and lack of } \\
\text { affordability. } \\
\text { Insufficient health services. }\end{array}$ & $\begin{array}{l}\text { Physical Infrastructure } \\
\text { (water, power, and } \\
\text { sanitation) Crises. } \\
\text { Provision of health and } \\
\text { education. }\end{array}$ & $\begin{array}{l}\text { Health and education } \\
\text { centres established at } \\
\text { all levels. } \\
\text { Provision of basic } \\
\text { utilities. }\end{array}$ \\
\hline $\begin{array}{l}\text { Spatial } \\
\text { Distribution } \\
\text { and Social } \\
\text { Cohesion }\end{array}$ & $\begin{array}{l}\text { Previously good relations (before } \\
\text { migration) have turned to limited } \\
\text { interaction due to political, cultural, } \\
\text { and social factors. } \\
\text { Discrimination in terms of benefit } \\
\text { provision. }\end{array}$ & $\begin{array}{l}\text { Secluded Settlements; } \\
\text { Continued violence }\end{array}$ & $\begin{array}{l}\text { Secluded during initial } \\
\text { phase, tensions with } \\
\text { Muslims. } \\
\text { Spread across entire } \\
\text { city area today with } \\
\text { concentration in few } \\
\text { localities; absorbed in } \\
\text { local communities. }\end{array}$ \\
\hline Participation & $\begin{array}{l}\text { Municipalities attend to their } \\
\text { enquiries and requests }\end{array}$ & $\begin{array}{l}\text { No mechanisms for } \\
\text { refugee's involvement. } \\
\text { Lack of factual knowledge. }\end{array}$ & $\begin{array}{l}\text { Participation was } \\
\text { ensured in decision } \\
\text { making. Refugees } \\
\text { participated willingly. }\end{array}$ \\
\hline
\end{tabular}

Table 1: Comparing Case Specific Strategies adopted for Refugee Resettlement 


\section{References}

1. Alert, I. (2015). Perceptions and Prescriptions: How Lebanese People View Their Security.

2. Alice Charles, D. G. (2017). World Economic Forum.

3. Amrita Paul, D. P. (2015). Pattern of Post 1947 Refugee Resettlement in India. International Journal of Geology, Agriculture and Environmental Sciences .

4. Bhatia, A. A. (2010). The decade that changed Delhi. Retrieved from Hindustan Times: https://www.hindustantimes.com/static/partition/delhi/\#: :text=Delhi\%2C\%20the\%20brash\%2C \%20bustling\%20Indian,and\%20Sikh\%20refugees\%20poured\%20in.

5. Bhavnani, N. (2014). he Making of the Exile: Sindhi Hindus and the Partition of India. Westland and Tranquebar Press.

6. Bhavnani, N. (2016). Unwanted Refugees: Sindhi Hindus in India and Muhajirs in Sindh. South Asia: Journal of South Asian Studies, 790-804.

7. Bruce Katz, L. N. (2016). Cities and refugees: The German experience. New York: Brookings.

8. Bruce Katz, L. N. (2016). Cities and Refugees: The German Experience. Retrieved from Brookings: https://www.brookings.edu/research/cities-and-refugees-the-german-experience/

9. $(1941,1951)$. Census of India.

10. Census, D. o. (1991). Map of Delhi, DCHB.

11. Committee, C. E. (1948). SWJN.

12. Congress, L. o. (2016). Refugee Law and Policy: Canada. Retrieved from loc.gov: https://www.loc.gov/law/help/refugee-law/canada.php

13. Dan, S. (2018). Refugees then and now: memory, history. Patterns of Prejudice, 101-106.

14. Datta, V. (1986). Delhi Through the Ages: Essays in Urban History, Culture and Society. Oxford India Paperbacks.

15. DDA. (1990). Delhi Metropolitan Area, Master Plan for Delhi Perspective.

16. DTCP, D. O. (1994). Bhopal Development Plan 2005.

17. Dupont, V. (2002). Socio-spatial differentiation and residential segregation in Delhi: a question of scale? Centre for Indian and South Asian Studies.

18. Dupont, V. (2004). Urban Development and Population Redistribution in Delhi: Implications for categorising Population. Burlington: Ashgate Publishing Company.

19. Forum, J. I. (2018). Syrian refugees in Jordan, A protection overview.

20. Francis, J. F. (2016, June). Remembering the 1971 refugees. Retrieved from Dhaka Tribune: https://www.dhakatribune.com/opinion/2016/06/20/remembering-1971-refugees

21. Gayer, L. (2012). Muslims in Indian Cities: Trajectories of Marginalisation. Hurst Publishers.

22. Gil Loescher, J. M. (2006). Protracted refugeesituations: the search for practical solutions, Chapter 5. Oxford Department of International Development. 
23. Hashmi, S. (2017). The Role of Partition in Making Delhi What It Is Today. The Wire. Retrieved from the wire.in.

24. International, W. V. (2015). Social Cohesion between Syrian Refugees and Urban Host Communities in Lebanon and Jordan.

25. Iyer, S. (2001). Reminiscing the Harsh Days. Sindhishaan.

26. Iyer, S. (2001). Reminiscing the Harsh Days, From Sagas Of Partition To Snags Of Settling. Retrieved from sindhishaan: http://www.sindhishaan.com/article/partition/part_01_00b.html

27. Jawabrah. Muain, B. U. (2016). Urban planning analyses of refugee camps, Jabalia as case studyGaza strip, Palestine. International Journal of Science and Research, 678-688.

28. JIPS. (2013). Urban Profiling of Refugee Situations in Delhi.

29. Kothari, R. (2009). The Burden of Refuge.

30. Lidhoo, A. R. (2016, August). Refugee colonies changed South Delhi's face. Retrieved from Hindustan Times: https://www.hindustantimes.com/delhi/refugee-colonies-changed-southdelhi-s-face/story-

qYpc00QI28vP5syqnvYYCO.html\#: :text=After\%20Partition\%2C\%20thousands\%20of\%20refugee s, became\%20home\%20to\%20Karachi's\%20elites.

31. Ltd, E. G. (1996). Eieher City Map of Delhi.

32. Madhumita, S. (2015). A study of migration from Bangladesh to Assam, India and its Impact,.

33. Manjulalwani, D. P. (2015). Relevance of Keynesian Trade Theory with Sindhi Economy.

34. (2013). Manual for UNRWA Employment Service Centres.

35. Moutafis, G. (2019). THE WORLD'S REFUGEES IN NUMBERS. Retrieved from https://www.amnesty.org/.

36. NCRPB. (1988). Landuse 1986-1987, Regional Plan 2001.

37. Pandey, G. (2001). Remembering Partition: Violence, Nationalism and History in India. Cambridge: Cambridge University Press.

38. Prashant Bharadwaj, A. K. (2008). The Big March: Migratory Flows After The Partition Of India.

39. Rebelo, E. M. (2010). A methodology to approach Immigrants' land use in Metropolitan areas. Cities, 137-153.

40. Rehabilitation of Refugees Coming from West Pakistan. (n.d.). Shodhganga.

41. Rehabilitation, M. o. (1953). Housing Schemes for displaced persons in Delhi.

42. Rueckert, P. (2017). 5 Of The Biggest Reasons Why People Become Refugees. Retrieved from https://www.globalcitizen.org/: https://www.globalcitizen.org/en/content/reasons-why-peoplebecome-refugees/

43. Sharma, M. (2009). Refugees in Delhi. Centre for Civil Society.

44. Shodhganga. (n.d.). Rehabilitation of Refugees Coming from West Pakistan.

45. UNCTAD. (2019). The Least Developed Countries Report. 
46. UNDP. (2019). Human Development Reports.

47. UNHCR. (2019). Camp strategy guidance (planned settlements). UN Refugee Agency.

48. UNHCR. (2019). Global Trends, Forced Displacement in 2018. Geneva: UNHCR.

49. Veronika Fajth, Ö. B. (2019). How do refugees affect social life in host communities? The case of Congolese refugees in Rwanda. Comparative Migration Studies volume 